\title{
Pelatihan Pembuatan dan Editing Video Bagi Guru SD untuk Menghadapi Era Industri 4.0
}

\author{
Yosi Nur Kholisho ${ }^{\text {, Baiq Desi Dwi Arianti*2, Jamaluddin }}{ }^{3}$, Rasyid Hardi Wirasasmita ${ }^{4}$, \\ Kholida Ismatulloh $^{5}$, M. Zamroni Uska ${ }^{6}$, Ahmad Fathoni ${ }^{7}$ \\ yosink.peninfo@gmail.com ${ }^{1}$, ariantibaiq@ hamzanwadi.ac.id*2, rasyidhw.p.informatika@ gmail.com ${ }^{4}$, \\ kholida.ebtaryadi@gmail.com ${ }^{5}$ \\ 1,2,3,4,5,6Pendidikan Informatika, Universitas Hamzanwadi
}

Received: 1 Juni 2021

DOI: 10.29408/ab.v2i1.3586
Accepted: 25 Juli $2021 \quad$ Online Published: 31 Juli 2021

URL: http://dx.doi.org/10.29408/ab.v2i1.3586

\begin{abstract}
Abstrak: Era Industri 4.0 mendorong para pendidik untuk dapat menerapkan teknologi informasi dalam proses pembelajaran. Salah satu penerapan teknologi dalam proses pembelajaran adalah penggunaan video pembelajaran. Apalagi pada masa pandemi Covid 19 saat ini yang menerapkan pembelajaran daring, video pembelajaran dapat menjadi alternatif sumber belajar. Akan tetapi pada kenyataannya banyak guru di Indonesia tidak memiliki kemampuan dalam membuat video pembelajaran. Pembelajaran daring saat ini kebanyakan hanya berupa pemberian materi dari buku pelajaran, diskusi melalui WA, mendatangi rumah siswa untuk memberikan tugas, dan lain-lain, sehingga belum maksimal. Oleh karena itu kegiatan pelatihan ini bertujuan untuk melatih guru-guru dalam membuat video pembelajaran, sehingga guru memiliki alternatif lain sebagai sumber belajar siswa. Kegiatan ini berupa pelatihan pembuatan dan editing video menggunakan aplikasi bandicam, Microsoft power point 2013, dan aplikasi Kinemaster. Hasil dari kegiatan ini adalah peserta/guru untuk aplikasi bandicam tingkat keberhasilan 100\%, Microsoft power point 2013 tingkat keberhasilan 100\%, kinemaster tingkat keberhasilan tahap pertama $70 \%$ selanjutnya tahap ke $2100 \%$.
\end{abstract}

Kata Kunci: Editing Video; Teknologi; Pembelajaran; Covid-19

\begin{abstract}
The Industrial 4.0 Era encourages educators to be able to apply information technology in the learning process. One application of technology in the learning process is the use of learning videos. Especially during the current Covid 19 pandemic that applies online learning, videos can be an alternative source for learning. However, in reality, many teachers in Indonesia cannot make learning videos. Online learning is currently mostly only in the form of providing material from textbooks, discussions via WA, visiting students' homes to give assignments, and so on, so it is not optimal. Therefore, this training activity aims to train teachers in making learning videos so that teachers have other alternatives as a source of student learning. This activity is in the form of training in making and editing videos using the Bandicam application, Microsoft PowerPoint 2013, and the Kinemaster application. The results of this activity are participants/teachers for the Bandicam application with a $100 \%$ success rate, Microsoft PowerPoint 2013 100\% success rate, Kinemaster the first stage success rate 70\%, then the second stage $100 \%$.
\end{abstract}

Keyword: Video Editing; Technology; Learning; Covid-19 
Kholisho, Y. N., Arianti, B. D. D., Jamaluddin, J., Wirasasmita, R. H., Ismatulloh, K., Uska, M. Z., \& Fathoni, A. (2021). Pelatihan pembuatan dan editing video bagi guru SD untuk menghadapi Era Industri 4.0. ABSYARA: Jurnal Pengabdian Pada Masyarakat, 2(1), 119-127. doi:10.29408/ab.v2i1.3586

\section{PENDAHULUAN}

Era Industri 4.0 atau yang biasa dikenal dengan revolusi industri 4.0 merupakan perkembangan bidang industri, dapat dilihat dari kemajuan dan pemanfaatan teknologi informasi yang kian berkembang guna menjadikan bidang industri lebih modern, efektif dan efisen. Kemajuan teknologi informasi pada era industri 4.0 tidak hanya berkembang untuk bidang industri saja melainkan pemerintahan, bidang pendidikan, kesehatan, dan lain-lain juga ikut memanfaatkan teknologi informasi tersebut dan tidak dapat dipisahkan dari kehidupan manusia (Yosi, 2020). Salah satunya dalam bidang pendidikan munculnya media-media pembelajaran online baik dalam bentuk aplikasi maupun yang dijabarkan pada website pembelajaran menjadi bukti bahwasanya dunia pendidikan juga mengalami kemajuan dalam penerapan teknologi informasi. Aplikasi pembelajaran melahirkan banyak terobosan baru dalam meningkatkan efisiensi dan efektifitas proses pembelajaran (Rasyid, dkk, 2020).

Menteri Pendidikan dan Kebudayaan Republik Indonesia Nomor 2 dan 3 Tahun 2020 tentang pencegahan dan penanggulangan Corona virus disease (Covid-19) menyatakan bahwa dilakukannya pembelajaran secara daring (dalam jaringan) dirumah (makarim dalam Kholisho, 2020). Pembelajaran daring merupakan suatu konsep pembelajaran dimana proses pembelajaran dilakukan di era 4.0 dengan berbantu teknologi dan internet (Mandailina, dkk., 2021). Penerapan pembelajaran daring merupakan upaya untuk meningkatkan kualitas pendidikan di Indonesia yang masih tergolong rendah hingga saat ini (Majid \& Fuada, 2020). Penerapan pembelajaran daring dapat diterapkan dengan cara memberikan materi pelajaran, melakukan diskusi dan pembelajaran langsung melalui online (Arif, dkk., 2018). Akan tetapi pada kenyataannya pembelajaran dengan proses daring sangat mengalami kendala.

Kendala dalam proses pembelajaran daring tidak hanya dialami pada daerah terpencil melainkan daerah perkotaan juga mengalami permasalahan serupa, yaitu kebutuhan kuota dan sinyal yang baik dalam proses pembelajaran secara daring. Permasalahan tersebut dialami dalam penerapan pembelajaran daring, disebabkan oleh guru menerapkan pembelajaran langsung melalui daring berbantu aplikasi zoom ataupun google meet (Herliandry, dkk., 2020). Pada semester selanjutnya mulailah muncul berbagai pertimbangan dari beberapa guru untuk menanggulangi permasalahan yang sama, yaitu beberapa guru mengubah penerapan pembelajaran dengan berbantu video call/conference melalui WA, google classroom, pemberian materi dan tugas dengan siswa bergantian mengambil di sekolah, dan guru home visit belajar dari rumah ke rumah siswa.

Permasalahan dalam proses pembelajaran daring dituangkan dalam penelitian dengan hasil bahwa permasalahan daring disebabkan oleh faktor ekonomi (38\%), faktor sosial (30\%), faktor kesehatan (19\%) dan faktor kepribadian (13\%) (Baety \& Munandar, 2021). Beberapa permasalahan dalam pembelajaran perhatian siswa kurang disebabkan oleh kebosanan mendengarkan guru pada saat menjelaskan, materi ajar yang diajarkan kurang dimengerti oleh siswa, guru mengalami kelelahan yang berakibat guru tidak bergairah dalam penyampaian materi ajar, kurangnya sarana pembelajaran siswa dalam menyelesaikan tugas dan belajar, sehingga pada akhirnya guru harus mampu membuat media pembelajaran yang inovatif dan kreatif sehingga menarik untuk siswa (Minardi \& Akbar, 2020). Selanjutnya penelitian lain menunjukkan bahwa kendala atau hambatan pertama adalah kondisi orang tua siswa yang lebih 
Kholisho, Y. N., Arianti, B. D. D., Jamaluddin, J., Wirasasmita, R. H., Ismatulloh, K., Uska, M. Z., \& Fathoni, A. (2021). Pelatihan pembuatan dan editing video bagi guru SD untuk menghadapi Era Industri 4.0. ABSYARA: Jurnal Pengabdian Pada Masyarakat, 2(1), $119-127$. doi:10.29408/ab.v2i1.3586

banyak menggunakan aplikasi WhatsApps (WA), kendala yang kedua adalah kesulitan mencari jaringan internet dan gawai telepon pintar yang lebih sering dibawa orang tua yang bekerja (Anugrahana, 2020). Berdasarkan kedua permasalahan tersebut dapat disimpulkan bahwa permasalahan ekonomi termasuk gadget hanya dimiliki oleh orang tua dan tidak terdapat sinyal internet menjadi permasalahan yang paling umum terjadi.

Pada awal November tahun 2020 seorang guru SD di salah satu sekolah swasta dan merupakan salah satu peserta PPG (Pendidikan Profesi Guru) di salah satu perguruan tinggi menceritakan permasalahan yang dihadapi yaitu ketidak mampuan dalam pembuatan media pembelajaran yang menarik, akan tetapi pembuatan media pembelajaran merupakan salah satu komponen yang wajib dikuasai oleh peserta PPG. Sejalan dengan hal tersebut selama proses pembelajaran disekolah asal selama masa pandemi Covid-19 dilaksanakan dengan metode daring, guru tersebut menjelaskan bahwa segala cara telah dilakukan dalam mengefektifkan proses pembelajaran di masa Covid-19, akan tetapi proses-proses tersebut tidak dapat dilakukan secara maksimal, bahkan proses tersebut dianggap gagal oleh guru tersebut. Metode terakhir yang dilakukan oleh guru tersebut adalah datang ke setiap rumah siswa (home visit) untuk mengajarkan siswanya, permasalahan timbul yaitu lonjakan penderita Covid-19 terus naik, sehingga wilayah guru tersebut berada pada zona merah, dan seluruh pembelajaran menjadi terhenti. Salah satu solusi yang dapat diberikan adalah guru membuat video pembelajaran yang berisi penjelasan langsung oleh guru dan menampilkan media yang menarik agar video tersebut menjadi lebih menarik, akan tetapi guru-guru tidak mampu untuk membuat video tersebut.

Berdasarkan permasalahan tersebut maka dilakukan pelatihan pembuatan editing video dengan tema dosen mengabdi untuk negeri. Kegiatan ini bertujuan untuk mengedukasi guru untuk mampu membuat sebuah video pembelajaran yang menarik, sehingga harapannya guru menjadi lebih kreatif dan pembelajaran menjadi lebih menyenangkan.

\section{METODE PELAKSANAAN}

\section{Waktu dan Lokasi}

Kegiatan pengabdian kepada masyarakat ini dilakukan dari tanggal 19 sampai 25 November 2020. Kegiatan ini dilakukan secara online dengan menggunakan zoom. Disebabkan oleh pelaksanaan kegiatan dilakukan secara online tempat kegiatan berada pada beberapa wilayah. Kegiatan pengabdian kepada masyarakat ini diikuti oleh 60 peserta yang berasal dari Propinsi Nusa Tenggara Barat, Nusa Tenggara Timur, dan Jawa.

\section{Prosedur pelaksanaan}

Tahapan pelaksanaan kegiatan pengabdian kepada masyarakat dilaksanakan secara online melalui zoom mulai tanggal 19 sampai 25 November 2020, kegiatan ini melibatkan dosen program studi pendidikan Informatika. Kegiatan pengabdian kepada masyarakat ini menggunakan metode:

1. Demonstrasi

Pada tahap ini, dilakukan proses penjelasan dan pendemonstrasian aplikasi yang disiapkan dalam proses pembuatan video, aplikasi yang dijelaskan pada pelatihan ini yaitu aplikasi bandicam, microsoft power point 2013, dan kinemaster. Pada tahap ini 
Kholisho, Y. N., Arianti, B. D. D., Jamaluddin, J., Wirasasmita, R. H., Ismatulloh, K., Uska, M. Z., \& Fathoni, A. (2021). Pelatihan pembuatan dan editing video bagi guru SD untuk menghadapi Era Industri 4.0. ABSYARA: Jurnal Pengabdian Pada Masyarakat, 2(1), $119-127$. doi:10.29408/ab.v2i1.3586

dilakukan secara perlahan sehingga guru-guru mampu memahami langkah demi langkah sehingga menghasilkan video yang baik. Pada tahap pelatihan diawali dengan pelatihan menggunakan bandicam, selanjutnya pelatihan perekaman penjelasan materi pembelajaran dengan menggunakan power point 2013 dan terakhir petihan pembuatan video pembelajaran yang lebih kompleks menggunakan kinemaster.

2. Praktik

Pada tahap praktik, dilakukan langsung setelah dilakukan demostrasi oleh tutor, sehingga apabila ditemukan kesulitan yang terjadi dapat langsung diatasi. Sama halnya seperti pada saat demonstrasi, hahap praktik diawali dengan editing video, perekaman dengan menggunakan bandicam, pada hari selanjutnya materi yang telah disiapkan oleh guru diberikan video penjelasan dengan menggunakan aplikasi microsoft power point 2013, dan pada hari terakhir pelatihan dilakukan perekaman dan editing video menggunakan kinemaster.

\section{HASIL DAN PEMBAHASAN}

HASIL

Berdasarkan pada uraian permasalahan yang ditemukan yaitu keresahan guru akan pelaksanaan pembelajaran ditengah pandemi Covid-19 yang terus angka penderitanya meningkat serta pelaksanaan pembelajaran yang kurang efektif serta kebutuhan akan kemampuan guru membuat media pembelajaran yang menarik dalam proses penyelesaian program PPG, maka dilakukan diskusi untuk mencari solusi atas permasalahan tersebut. Solusi yang diberikan adalah pelaksanaan pelatihan pembuatan dan editing video pembelajara, sehingga uraian pelaksanaan kegiatan diuraikan sebagai berikut:

Tabel 1. Uraian Pelaksanaan Kegiatan PKM

\begin{tabular}{lll}
\hline No. & Hani, & Uraian Kegiatan
\end{tabular}

\begin{tabular}{|c|c|c|c|}
\hline 1 & $\begin{array}{l}19 \\
\text { November } \\
2020\end{array}$ & $\begin{array}{l}\text { Koordinasi kegiatan dengan } \\
\text { koorprodi dan dekan serta } \\
\text { penyusunan rangkaian } \\
\text { kegiatan dan pemilihan tutor }\end{array}$ & $\begin{array}{l}\text { - Kesepakatan dan persetujuan kegiatan } \\
\text { - Tersusun rangkaian acara } \\
\text { - Terbentuknya design flayer }\end{array}$ \\
\hline 2 & $\begin{array}{l}20 \\
\text { November } \\
2020\end{array}$ & $\begin{array}{l}\text { Penyebaran } \\
\text { flayer/Pengumuman/Informasi }\end{array}$ & $\begin{array}{l}\text { - Tersampaikannya flayer kepada peserta } \\
\text { - } \text { Adanya pendaftar kegiatan }\end{array}$ \\
\hline 3 & $\begin{array}{l}21 \\
\text { November } \\
2020\end{array}$ & $\begin{array}{l}\text { Pelaksanaan Kegiatan Hari } 1 \\
\text { (pelatihan bendicam) }\end{array}$ & $\begin{array}{l}\text { - } 60 \text { orang peserta mampu melakukan editing } \\
\text { video dan perekaman menggunakan } \\
\text { aplikasi bandicam sehingga tingkat } \\
\text { keberhasilan yaitu } 100 \%\end{array}$ \\
\hline
\end{tabular}


Kholisho, Y. N., Arianti, B. D. D., Jamaluddin, J., Wirasasmita, R. H., Ismatulloh, K., Uska, M. Z., \& Fathoni, A. (2021). Pelatihan pembuatan dan editing video bagi guru SD untuk menghadapi Era Industri 4.0. ABSYARA: Jurnal Pengabdian Pada Masyarakat, 2(1), $119-127$. doi:10.29408/ab.v2i1.3586

\begin{tabular}{|c|c|c|c|}
\hline 4 & $\begin{array}{l}22 \\
\text { November } \\
2020\end{array}$ & $\begin{array}{l}\text { Pelaksanaan Kegiatan Hari } 2 \\
\text { (pelatihan microsoft power } \\
\text { point 2013) }\end{array}$ & $\begin{array}{l}60 \text { orang peserta mampu melakukan editing } \\
\text { video dan perekaman menggunakan } \\
\text { aplikasi microsoft power point } 2013 \\
\text { sehingga tingkat keberhasilan yaitu } 100 \%\end{array}$ \\
\hline 5 & $\begin{array}{l}23 \\
\text { November } \\
2020\end{array}$ & $\begin{array}{l}\text { Pelaksanaan Kegiatan Hari } 3 \\
\text { (pelatihan kinemaster) }\end{array}$ & $\begin{array}{l}\text { Dari } 60 \text { orang peserta terdapat } 42 \text { orang } \\
\text { peserta mampu melakukan editing video } \\
\text { dan perekaman menggunakan aplikasi } \\
\text { kinemaster sehingga tingkat keberhasilan } \\
\text { yaitu } 70 \%\end{array}$ \\
\hline 6 & $\begin{array}{l}24 \\
\text { November } \\
2020\end{array}$ & $\begin{array}{l}\text { Pelaksanaan Kegiatan Hari } 4 \\
\text { (pelatihan lanjutan } \\
\text { kinemaster) } \\
\text { Publish video ke Youtube } \\
\text { Penutupan }\end{array}$ & 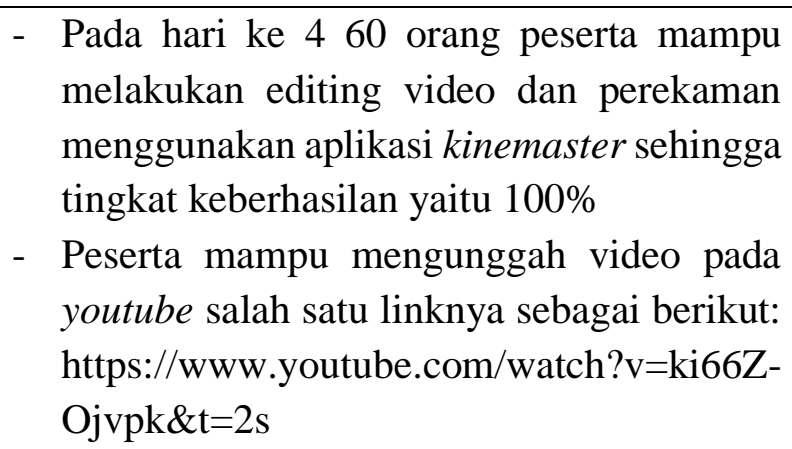 \\
\hline 7 & $\begin{array}{l}25 \\
\text { November } \\
2020\end{array}$ & $\begin{array}{l}\text { Pembagian Sertifikat, Evaluasi } \\
\text { Program }\end{array}$ & $\begin{array}{l}\text { - Peserta mendapatkan sertifikat } \\
\text { - Dihasilkannya evaluasi kekurangan dan } \\
\text { kelebihan kegiatan pelatihan pembuatan } \\
\text { dan editing video }\end{array}$ \\
\hline
\end{tabular}

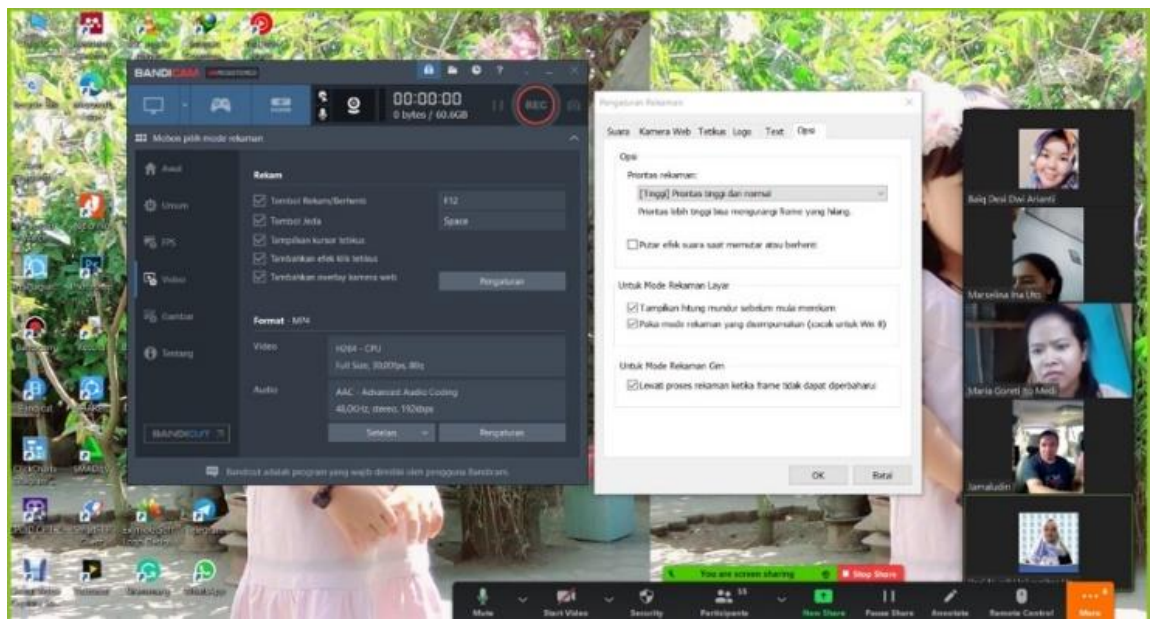

Gambar 1. Proses penjelasan penggunaan software 

dan editing video bagi guru SD untuk menghadapi Era Industri 4.0. ABSYARA: Jurnal Pengabdian Pada Masyarakat, 2(1), 119-127. doi:10.29408/ab.v2i1.3586

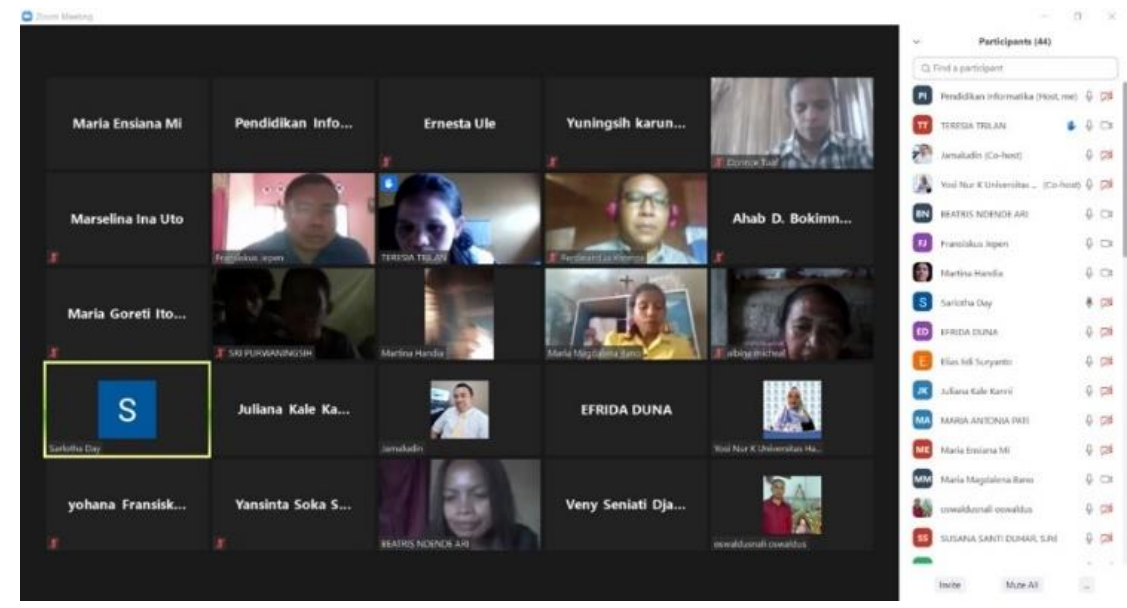

Gambar 2. Proses Praktik Pembuatan video

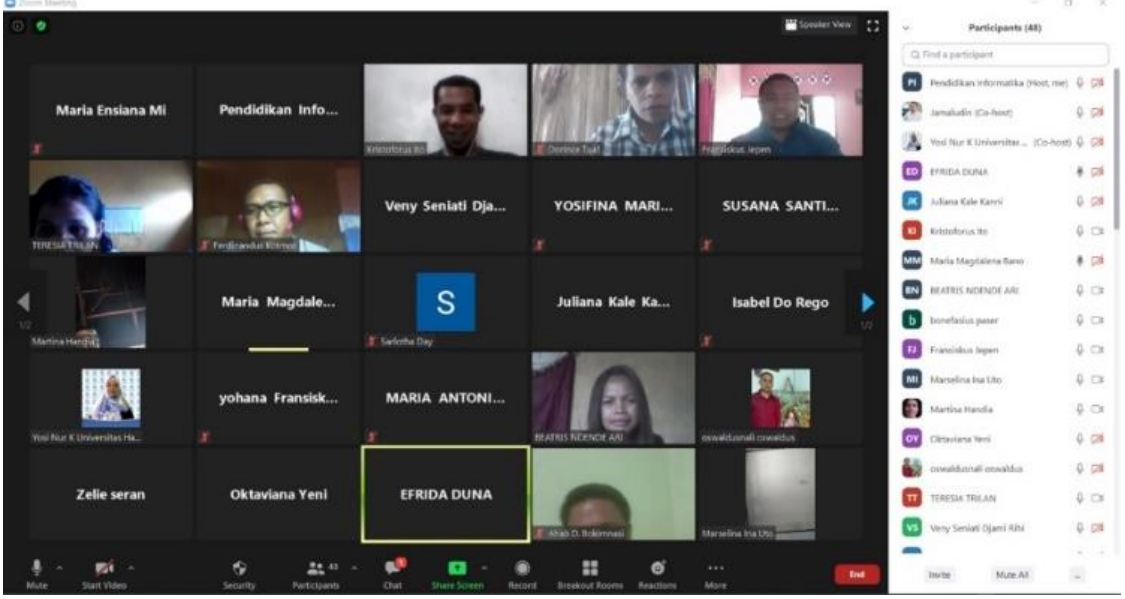

Gambar 3. Sesi Tanya Jawab

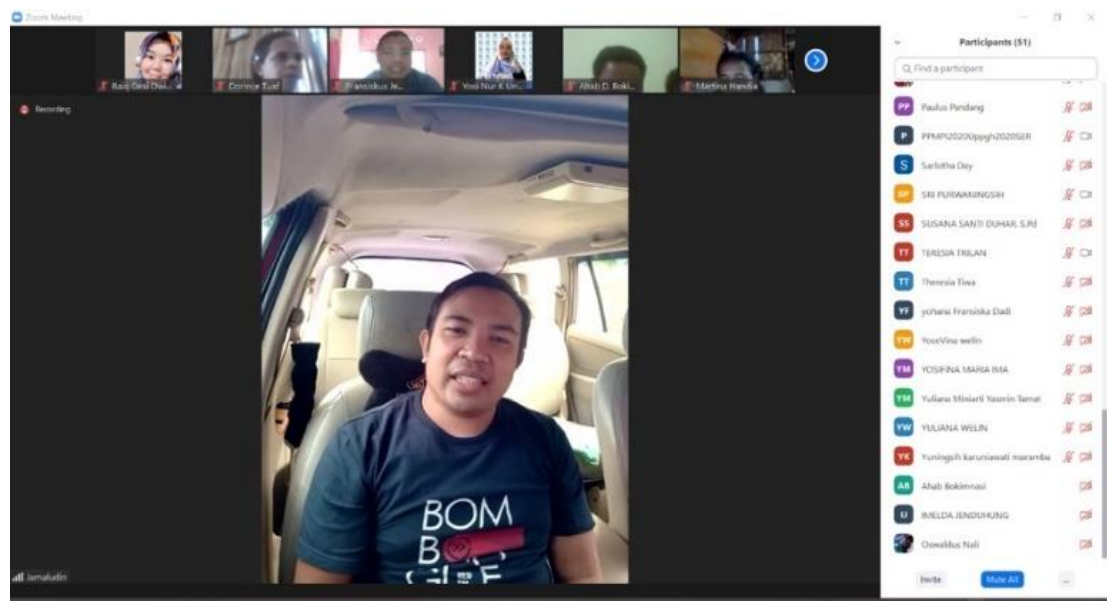

Gambar 4. Penutupan 

dan editing video bagi guru SD untuk menghadapi Era Industri 4.0. ABSYARA: Jurnal Pengabdian Pada Masyarakat, 2(1), $119-127$. doi:10.29408/ab.v2i1.3586

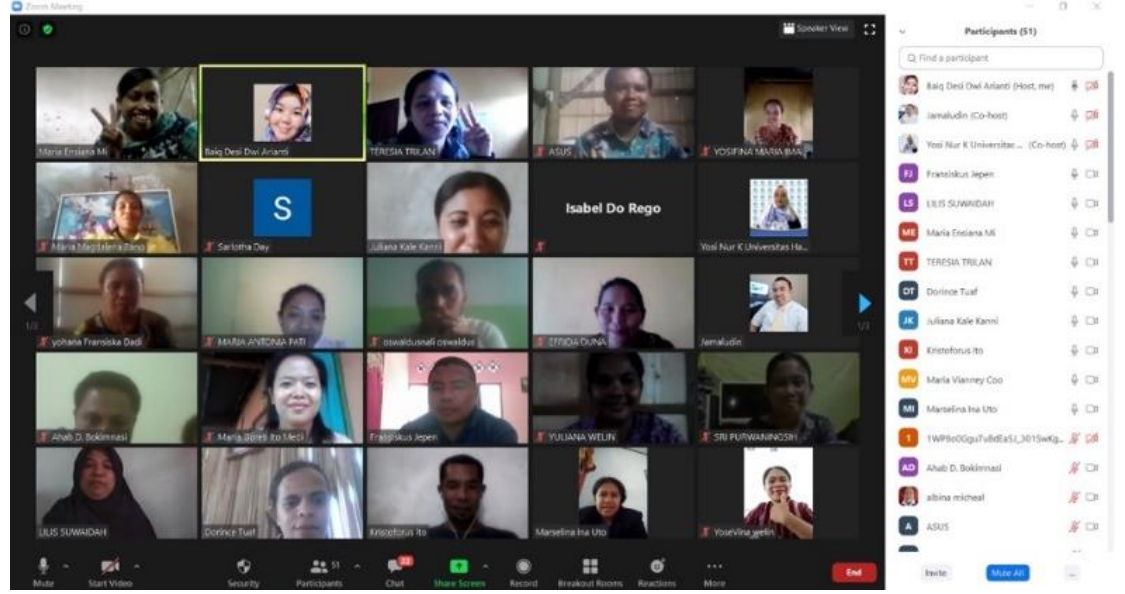

Gambar 5. Foto Bersama Peserta

\section{PEMBAHASAN}

Pembelajaran daring merupakan suatu konsep pembelajaran dimana proses pembelajaran dilakukan di era 4.0 dengan berbantu teknologi dan internet yang mana dalam hal ini para guru didorong untuk membuat media pembelajaran online sebagai salah satu penunjang dalam proses pembelajaran untuk meningkatkan ketertarikan para siswa. Penerapan pembelajaran daring merupakan upaya untuk meningkatkan kualitas pendidikan di Indonesia yang masih tergolong rendah hingga saat ini (Majid \& Fuada, 2020). Salah satu caranya adalah memberikan berbagai macam pelatihan dan pengajaran kepada para guru untuk merubah pola pengajaran yang biasa menjadi lebih variatif dan inovatif salah satunya dengan cara menggunakan model yang tepat dan media pembelajaran yang sesuai dengan kondisi saat ini. Keberhasilan dari suatu model pembelajaran tergantung dari karakteristik siswa (Dewi, 2020) Sebagaimana yang diungkapkan oleh Nakayama \& Yamamoto (2007) bahwa dari semua literature dalam e -learning mengindikasikan bahwa tidak semua siswa akan sukses dalam pembelajaran online. Ini dikarenakan fakor lingkungan belajar dan karakteristik siswa.

Menurut Dewi (2020) dampak yang dirasakan guru yaitu tidak semua mahir menggunakan teknologi internet atau media social sebagai sarana pembelajaran, bebera guru senior belum sepenuhnya mampu menggunakan perangkat atau fasilitas untuk menunjang kegiatan pembelajaran online dan perlu pendampingan dan pelatihan terlebih dahulu.

Pelatihan pembuatan dan editing video menggunakan aplikasi bandicam, Microsoft power point 2013, kinemaster, diawali dari resahnya guru-guru dalam menghadapi pembelajaran di masa Covid-19, berbagai cara telah dilakukan hingga mendatangi rumah masing-masing siswa akan tetapi dengan lonjakan orang yang terpapar maka guru tidak dapat lagi datang ke rumah siswa, salah satu cara yang dapat dilakukan dengan penggunaan video pembelajaran yang akan disesuaikan dengan kemampuan siswa. Pada proses pendaftaran yang hanya 1 hari di peroleh peserta sejumlah 60 peserta, hal ini menunjukkan bahwa guru sangat antusias untuk berinovasi agar pembelajaran dapat terserap dengan maksimal oleh siswa.

Pelaksaan pelatihan tutor berasal dari dosen pendidikan Informatika Universitas Hamzanwadi, dalam tahapan pelatihan waupun ditemui beberapa kendala yaitu masalah sinyal akan tetapi guru tetap antusias mengikuti dan bertanya pada bagian yang dirasa sulit untuk dipahami. Berdasarkan hasil pelatihan yang telah dilakukan dari ketiga aplikasi tersebut 
Kholisho, Y. N., Arianti, B. D. D., Jamaluddin, J., Wirasasmita, R. H., Ismatulloh, K., Uska, M. Z., \& Fathoni, A. (2021). Pelatihan pembuatan dan editing video bagi guru SD untuk menghadapi Era Industri 4.0. ABSYARA: Jurnal Pengabdian Pada Masyarakat, 2(1), $119-127$. doi:10.29408/ab.v2i1.3586

aplikasi yang dirasa paling sulit dipraktikkan oleh guru-guru yaitu pada aplikasi kinemaster, yaitu pada pelatihan aplikasi bandicam dan Microsoft power point 2013 seluruh peserta yaitu 60 orang mampu menggunakan dan melakukan pembuatan video menggunakan aplikasi tersebut sehingga tingkat keberhasilan yaitu 100\%. Akan tetapi untuk aplikasi kinemaster pada hari ke 3 yaitu 42 orang paham dan mampu membuat video sederhana dengan aplikasi tersebut sehinggan tingkat keberhasilan $70 \%$, pada hari ke 4 proses penjelasan dan praktik penggunaan aplikasi kinemaster 60 orang peserta mampu membuat video sederhana tetapi menarik sehingga pada hari terakhir tersebut yaitu hari ke 4 tingkat keberhasilan penggunaan aplikasi kinemaster sebesar $100 \%$. Hasil tersebut sejalan dengan hasil pengabdian serupa dengan hasil: setelah mengikuti pelatihan Media pembelajaran ini, nampak peningkatan pengetahuan Guru yang mengikuti pelatihan (Azima, 2020). Guru-guru yang menjadi peserta pelatihan mampu membuat video pembelajaran sebagai materi ajar menggunakan media berbasis teknologi informasi dan internet mendukung proses pembelajaran secara daring (Syahroni, dkk., 2020). Respon yang diberikan oleh peserta setelah pelaksanaan kegiatan menyampaikan kebermanfaatan pelatihan pembuatan dan editing video, yaitu peserta mampu untuk menuntaskan tugas dalam upaya penyelesaian kegiatan PPG serta dalam penerapan pembelajaran dikelas siswa merasa lebih paham dalam memahami materi walaupun kegiatan pembelajaran tidak dilakukan secara tatap muka atau pembelajaran langsung. Video tersebut dapat diputar oleh siswa kapanpun dan dapat diulang kembali apabila siswa mengalami kebingungan.

\section{SIMPULAN}

Pelatihan pembuatan dan editing video membuka wawasan dan kreatifitas guru dalam memanfaatkan teknologi informasi dalam menyampaikan materi pembelajaran. Walaupun tetap akan ditemui kendala akan tetapi proses pembelajaran dengan menggunakan video dapat meminimalisir terjadinya kontak dengan siswa. Dengan penguasaan guru dalam pembuatan video dapat juga diterapkan dalam pembelajaran luring apabila masa Covid-19 telah berakhir sehingga pembelajaran lebih menarik. Berdasarkan hasil wawancara serta respon dari peserta pelatihan menyatakan bahwa manfaat dari proses pelatihan ini adalah terselesaikannya tugas dalam kegiatan pendidikan profesi guru (PPG) yang komponenya adalah mampu membuat media pembelajaran yang menarik serta pelaksanaan pembelajaran di sekolah asal yang tidak dapat ditinggalkan walaupun dengan kondisi mengikuti kegiatan PPG berjalan efektif dengan bantuan media pembelajaran tersebut

\section{PERNYATAAN PENULIS}

Artikel ini merupakan hasil program pengabdian kepada masyarakat untuk mendukung pelaksanaan kegiatan Pendidikan Profesional Guru (PPG) dan tidak pernah dipublikasikan pada jurnal ilmiah manapun.

\section{DAFTAR PUSTAKA}

Anugrahana, A. (2020). Hambatan, solusi dan harapan: pembelajaran daring selama masa pandemi Covid-19 oleh guru sekolah dasar. Scholaria: Jurnal Pendidikan dan Kebudayaan, 10(3), 282-289. 
Kholisho, Y. N., Arianti, B. D. D., Jamaluddin, J., Wirasasmita, R. H., Ismatulloh, K., Uska, M. Z., \& Fathoni, A. (2021). Pelatihan pembuatan dan editing video bagi guru SD untuk menghadapi Era Industri 4.0. ABSYARA: Jurnal Pengabdian Pada Masyarakat, 2(1), $119-127$. doi:10.29408/ab.v2i1.3586

Arif, A., Istyadji, M., \& Syahmani, S. (2018). Implementasi Problem Based Learning Berbantuan Diskusi Daring Terhadap Kemampuan Pemecahan Masalah Dan Hasil Belajar Kimia Pada Materi Larutan Penyangga. JCAE (Journal of Chemistry And Education), 1(3), 237-244.

Azima, M. F. (2020). Pengembangan Dan Pelatihan Media Pembelajaran Bagi Guru SD IT Di Bandar Lampung. Jurnal Publika Pengabdian Masyarakat, 1(02), 48-52.

Baety, D. N., \& Munandar, D. R. (2021). Analisis Efektifitas Pembelajaran Daring Dalam Menghadapi Wabah Pandemi Covid-19. Edukatif: Jurnal Ilmu Pendidikan, 3(3), 880989.

Dewi, W. A. F. (2020). Dampak Covid-19 terhadap implementasi pembelajaran daring di Sekolah Dasar. Edukatif: Jurnal Ilmu Pendidikan, 2(1), 55-61.

Herliandry, L. D., Nurhasanah, N., Suban, M. E., \& Kuswanto, H. (2020). Pembelajaran pada masa pandemi Covid-19. JTP-Jurnal Teknologi Pendidikan, 22(1), 65-70.

Mandailina, V., Syaharuddin, S., Pramita, D., Ibrahim, I., \& Haifaturrahmah, H. (2021). Pembelajaran Daring Dalam Meningkatkan Motivasi dan Hasil Belajar Peserta Didik Selama Pandemi Covid-19: Sebuah Meta-Analisis. Indonesian Journal of Educational Science (IJES), 3(2), 120-129.

Majid, N. A., \& Fuada, S. (2020). E-Learning for Society: A Great Potential to Implement Education for All (EFA) Movement in Indonesia. 14(2), 250-258. Retrieved from https://www.learntechlib.org/p/216581/

Minardi, J., \& Akbar, A. S. (2020). Pelatihan Pengembangan Media Pembelajaran Interaktif dengan Power Point untuk Peningkatan Kompetensi Guru SD. E-Dimas: Jurnal Pengabdian kepada Masyarakat, 11(1), 96-100.

Nakayama, M., Yamamoto, H., \& Santiago, R. (2007). The Impact of Learner Characteristics on Learning Performance in Hybrid Courses among Japanese Students. Electronic Journal of E-Learning, 5(3), 195-206.

Syahroni, M., Dianastiti, F. E., \& Firmadani, F. (2020). Pelatihan Media Pembelajaran Berbasis Teknologi Informasi untuk Meningkatkan Keterampilan Guru dalam Pembelajaran Jarak Jauh. International Journal of Community Service Learning, 4(3), 170-178.

Wirasasmita, R. H., Arianti, B. D. D., Uska, M. Z., Kholisho, Y. N., \& Wardi, Z. (2020). Edukasi Zero Waste berbasis teknologi informasi. ABSYARA: Jurnal Pengabdian Pada Masyarakat, 1(2), 35-42.

Kholisho, Y. N., \& Lutfi, S. (2020, May). The Development Of Augmented Reality For Hardware Introduction For SDU Hamzanwadi Students. In Journal of Physics: Conference Series (Vol. 1539, No. 1, p. 012009). IOP Publishing. 